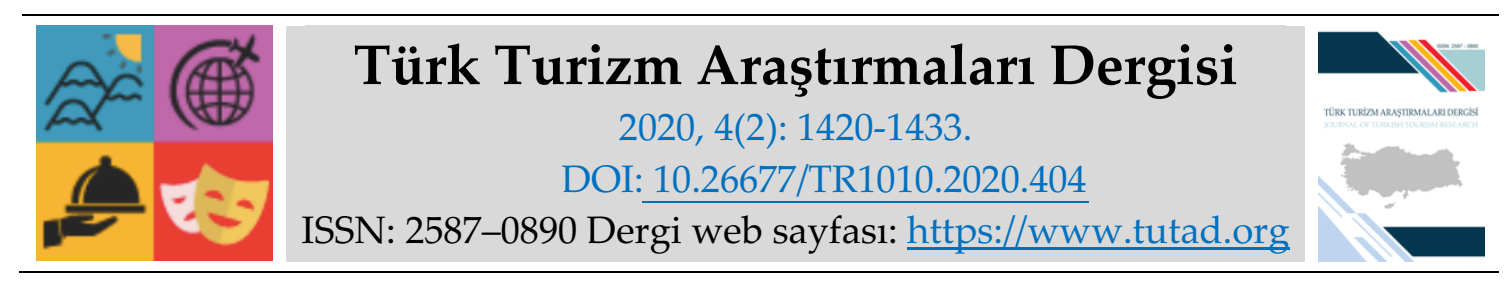

ARASTTIRMA MAKALESI

\title{
Turistlerin Destinasyon Aşinalığı ve Marka Eşitliği Algılarının Seyahat Niyetlerine Etkisi: İstanbul Örneği
}

Dr. Öğr. Üyesi Aydın ÜNAL, Kırklareli Üniversitesi, Pınarhisar Meslek Yüksekokulu, Kırklareli, e-posta: aydin.unal@klu.edu.tr ORCID: https://orcid.org/0000-0002-6377-8587

Öz

Destinasyon pazarlamasında destinasyonlar arası marka eşitliğini veya üstünlügüunü vurgulamak adına yoğun şekilde destinasyonların eşsizlikleri, sundukları hizmetlerin çeşitliliği ve kalitesi vurgulanmaktadır. Ancak alanyazında turistlerin seyahat niyetlerine destinasyon marka eşitliği boyutlarının ve destinasyon aşinalıklarının etkisini ölçen çalışmalar oldukça sınırlıdır. Bu kapsamda çalışmada İstanbul destinasyonunu Ağustos-Kasım 2019 döneminde ziyaret eden ve Ortadoğu ülkelerinden gelen turistlerin seyahat niyetlerine destinasyon marka eşitliği ve destinasyon aşinalığı boyutlarının etkisinin belirlenmesi amaçlanmaktadır. Bu kapsamda hazırlanan 430 anket formu turistlere yüzyüze iletişim kurularak uygulanmıştır. Anketlerden elde edilen veriler (400 anket) SPSS programında analize tabi tutulmuştur. Yapılan analizlerde; destinasyon marka eşitliği ölçeğinin destinasyon farkındalık algısı, destinasyon imaj algısı, destinasyon kalite algisı ve destinasyon sadakat algısı boyutlarından oluştuğu sonucuna ulaşılmıştır. Ayrıca tüm destinasyon marka eşitliği boyutlarının turistlerin destinasyon seyahat niyetlerini ve yine turistlerin destinasyon aşinalıklarının destinasyon seyahat niyetlerini yüksek ve pozitif düzeyde etkilediği sonucuna ulaşılmıştır.

Anahtar Kelimeler: Destinasyon Marka Eşitliği, Destinasyon Aşinalığı, Destinasyon Farkındalığı, Seyahat Niyeti, İstanbul.

Makale Gönderme Tarihi: 01.02.2020

Makale Kabul Tarihi: 09.04.2020

\footnotetext{
Önerilen Atıf:

Ünal, A. (2020). Turistlerin Destinasyon Aşinalığı ve Marka Eşitliği Algılarının Seyahat Niyetlerine Etkisi: İstanbul Örneği, Türk Turizm Araştırmaları Dergisi, 4(2): 1420-1433.

(C) 2020 Türk Turizm Araştırmaları Dergisi.
} 


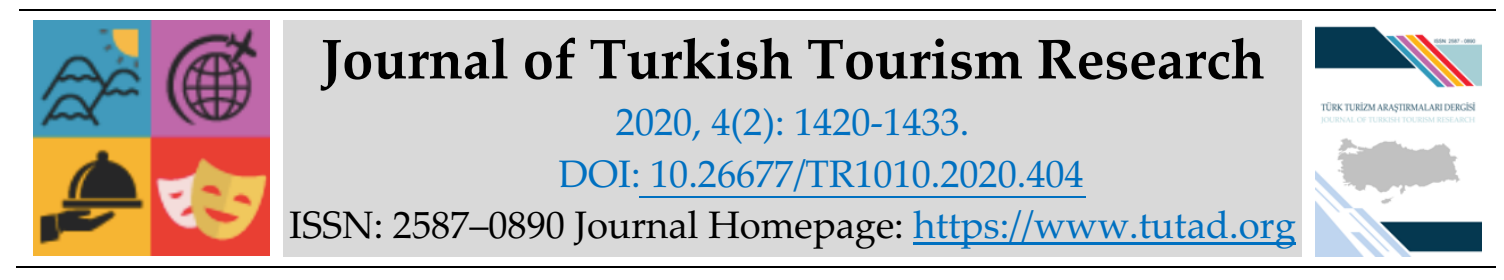

\title{
$\underline{\text { RESEARCH PAPER }}$
}

\section{The Effect Destination Familiarity and Brand Equality Perceptions of Tourists on Travel Intentions: The Case of İstanbul}

Assistant Prof. Dr. Aydın ÜNAL, Kırklareli University, Pınarhisar Vocational School, Kırklareli, e-mail: aydin.unal@klu.edu.tr ORCID: https://orcid.org/0000-0002-6377-8587

\begin{abstract}
In the marketing of destinations; the uniqueness of the destinations, the variety and quality of the services they offer are emphasized intensively in order to emphasize the brand equality or superiority among the destinations. However, studies in the literature that measure the effect of destination brand equality dimensions and destination familiarity on the travel intentions of tourists are very limited. In this study, it is aimed to determine the effects of destination brand equality and destination familiarity dimensions on the travel intentions of tourists from the Middle East countries who visited the Istanbul destination in the August-November 2019 period. 430 questionnaire forms prepared within this scope were applied to the tourists by communicating face to face. The data obtained from the questionnaires (400 questionnaires) were analyzed by use of the SPSS program. As a result of the analyzes, it was concluded that the scale of destination brand equality consisted of the dimensions of destination awareness perception, destination image perception, destination quality perception and destination loyalty perception. In addition, it was determined that all of the destination brand equality dimensions and destination familiarity of tourists affected destination travel intentions of tourists at high and positive levels.
\end{abstract}

Keywords: Destination Brand Equity, Destination Familiarity, Destination Awareness, Travel Intention, İstanbul.

Received: 01.02.2020

Accepted: 09.04.2020

\section{Suggested Citation:}

Ünal, A. (2020). The Effect Destination Familiarity and Brand Equality Perceptions of Tourists on Travel Intentions: The Case of İstanbul, Journal of Turkish Tourism Research, 4(2): 1420-1433.

(C) 2020 Türk Turizm Araştırmaları Dergisi. 


\section{Gíriş}

Destinasyonlar yerel ve küresel ölçekte yoğun bir rekabet ortamı içerisinde varlıklarını sürdürmeye çalışmaktadırlar. Bu süreçte diğer destinasyonlardan farklılıklarını ortaya koymak adına imaj, markalaşma, hizmet kalitesini arttırma, reklam ve tanıtım, marka aşinalığı ve sadakat oluşturma, vb. birçok faaliyeti birlikte yürütmektedirler (Garcia vd., 2012:646-647). Ancak çoğu zaman destinasyonları ve sundukları olanakları kullanan turistlerin bakış açısıyla yürütülen bu faaliyetlerin değerlendirilmesi noktasında eksiklikler yaşanabilmektedir (Chi vd., 2020:1). Bu çalışmada İstanbul ilini ziyaret eden ve Ortadoğu ülkelerinden gelen yabancı turistlerin seyahat niyetlerine destinasyon marka eşitliği ve destinasyon aşinalığı boyutlarının etkisinin belirlenmesi amaçlanmaktadır. Çalışmanın konusu ve ölçeği itibariyle ilgili alanyazında hissedilen kuramsal çerçeve ve uygulama temelli sonuç eksikliğinin giderilmesi adına önemli katkılar sağlayacağı düşünülmektedir. Çünkü araştırma kapsamında oluşturulan Destinasyon Marka Eşitliği (DME), Destinasyon Aşinalığı (DA) ve Seyahat Niyeti (SN) DME-DA-SN modeli daha önce sadece Chi vd., (2020) çalışmalarında test edilmiştir. Ayrıca araştırma modeli ve elde edilen sonuçlar kapsamında turistlerin seyahat niyetlerine; destinasyon aşinalığının ve destinasyon marka eşitliğinin ne kadar etki edebileceği ve bu süreçte etkili olan boyutların daha net analiz edilebileceği düşünülmektedir. Diğer taraftan turistlerin destinasyonlarda algıladıkları marka eşitliği (algılanan kalite, marka imajı, marka sadakati ve marka farkındalığı) ve destinasyon aşinalığı boyutlarının seyahat niyetlerine etkilerinin incelenmesi ve tartışılması adına çalışma verilerinin önemli sonuçlara ulaştıracağı düşünülmektedir. Bu çerçevede çalışmada öncelikle araştırmanın kuramsal çerçevesi oluşturulmuştur ve konu ile ilgili yapılmış diğer çalışmalar özetlenmiştir. Daha sonra araştırma yöntemi tasarlanmıştır, araştırma modeli ve ilgili araştırma hipotezleri çerçevesinde gerekli analizler uygulanmıştır ve araştırma bulgularına ulaşılmıştır. Araştırma da son olarak araştırma bulguları kısaca özetlenerek sonuç ve tartışma bölümü oluşturulmuştur.

Turistlerin destinasyon seçim süreçlerinde önceki deneyimleri, memnuniyet değerlendirmeleri, bilgi birikimleri, destinasyonun imajı, farklılığı, kalitesi, vb. birçok faktör etkili olabilmektedir (Gürsoy ve McCleary, 2004:353; Taşçı ve Knutson, 2010:85; Chen ve Lin, 2012:339). Ancak bu süreçte destinasyon marka eşitliği boyutları (imaj, kalite, sadakat ve farklılık) (Chi, vd., 2020:6) ve turistlerin destinasyon aşinalık düzeyleri önemli belirleyicilerdendir (Baloğlu, 2001:41; Kim ve Kim, 2005:549; Pike ve Bianchi, 2013:13-15). Bu faktörler temelinde ise turistlerin bilgileri olmayandan uzak durma, bilinmeyenin kaygısından kurtulma, tanıdık ve bilindik yani aşina olanı tercih etme, vb. algıları ve duygusal değerlendirmeleri yer almaktadır (Gürsoy ve McCleary, 2004:353; Kim ve Kim, 2005:550). Destinasyon markası kavramı bir yere ilişkin logo, isim, grafik, vb. ayırt edici farklılıkların toplamı şeklinde tanımlanmaktadır. Turistlerin zihinlerinde bir yerin ayırt edici ve marka olmasında o yerin turistlere potansiyel deneyim hissini verebilmesi gerekmektedir (Ritchie ve Ritchie, 1998:165). Destinasyon pazarlamasında marka çalışmalarında farklılık arzeden noktaların ön plana çıkarılarak vurgulanması önemli bir stratejik araç olarak kullanılmaktadır. Ancak marka eşitliği kavramı, boyutları ve stratejisi genellikle göz ardı edilmektedir. Marka eşitliği en basit haliyle; "bir markanın pazarlanabilmesi için tüketicilerinin tepkileri üzerinde markayla ilgili bilgilerin farklı etkileri" şeklinde tanımlanmaktadır (Keller, 2003:7). Destinasyon marka eşitliği ise ilgili tanımın destinasyonlara uyarlanmasına imkân vermektedir ve algısal eşitlik yönüyle öne çıkmaktadır. Destinasyon marka eşitliği boyutları yapılan çeşitli araştırmaların sonuçları çerçevesinde imaj (destinasyonla ilgili turistlerin zihinlerindeki bağlantıların toplamı), kalite (destinasyonun turistin beklentilerini karşılama düzeyi), sadakat (destinasyona yönelik turistlerin bağlllık düzeyi) ve farklılık (destinasyonla ilgili turistlerin algılarındaki değerlendirme düzeyleri) şeklinde adlandırılmışlardır (Chi vd., 2020:2). Destinasyon marka eşitliği boyutları destinasyonları 
pazarlama ve tutundurma çalışmalarında önemli bir yere sahiptirler. İlgili boyutlar çok sayıda somut ve soyut bileşenden oluşmaktadırlar ve turistler destinasyon seçim süreçlerinde ilgili boyutların fiziksel ve psikolojik etkileri çerçevesinde hareket etmektedirler ve karar vermektedirler (Boo vd., 2009). Destinasyon aşinalığ 1 ise bir destinasyonu ilk kez veya tekrardan ziyaret eden turistler arasındaki davranışsal farklılıkları çeşitli yönleriyle açıklamaya çalışan bir kavramdır. Aşinalık düzeyi bir destinasyon hakkındaki imaj, marka, seyahat niyeti ve diğer birçok algının bireysel anlamda biçimlenmesine etki etmektedir. Destinasyon aşinalığı fazla olan turistlerin aşinalığı olmayan ya da kısıtlı olan turistlere göre destinasyon hakkında kaygıları ve endişeleri daha düşük düzeydedir ve kendilerine güvenleri oldukça yüksektir (Milman ve Pizam, 1995:21; Lepp ve Gibson, 2003:606; Chen ve Lin, 2012:339). Turistler daha önceden bilgilerinin olmadığı turistik destinasyonları ve ürünleri deneyimlemeleri durumunda yaşayabileceklerini düşündükleri olumsuzluklardan ve kayıplardan dolayı deneyimlemek ve satın almak istemeyebilmektedirler. Bu süreçte turistler açısından bilgi arama çabaları ve bilgi edinme araçları önem kazanmaktadır. Turistlerin bilgi edinme süreçlerinde öncelikle başvurdukları kaynaklar ise zihinlerindeki önceki bilgileri ve deneyimleridir (Chen ve Gürsoy, 2000). Sahip oldukları bilgilerin ve deneyimlerin düzeyi ise satın almayı düşündükleri destinasyonlar ve turistik ürünlerle ilgili algıladıkları risklerin ve kaygıların düzeyini ters orantılı şekilde etkilemektedir (Lepp ve Gipson, 2003). Turistlerin bilgi ve aşinalık düzeyleri arttıkça turistlerin algıladıkları risk düzeyi ve duydukları güven düzeyi artmaktadır ve bu durum satın alma ve tekrar ziyaret niyetinin oluşmasına olumlu katkılar sağlamaktadır (Milman ve Pizam, 1995; Baloğlu, 2001; Chi vd., 2000). DME-DA-SN modeli çerçevesinde yapılmış çalışmalar genel olarak DME boyutların (Murphy vd., 2007; Yoon ve Uysal, 2005; Arendt ve Brettel, 2010; Ferns ve Walls, 2012) ve DA boyutunu (Baloğlu, 2001; Lin vd., 2014) bağımsız şekilde ele alarak turistlerin seyahat niyetlerine etkilerini belirleme odaklı yürütülmüştür.

\section{İLGILII ARAŞTIRMALAR}

Bu çalışmaya konu edilen DME-DA-SN modeli sadece Chi vd., (2020:7) tarafından test edilmiştir ve destinasyon marka eşitliği ve destinasyon aşinalığı boyutlarının bir bütün olarak turistlerin seyahat niyetlerine etkileri belirlenmeye çalışılmıştır. Vietnam'da Hanoi, Ho Chi Minh ve Danang destinasyonlarını Şubat-Mayıs 2018 döneminde ziyaret eden 531 yabancı turist ile yürütülen çalışmada destinasyon marka eşitliği ve destinasyon aşinalığ boyutlarının, turistlerin destinasyon seyahat niyetleri üzerine ve destinasyon aşinalı̆̆ boyutunun destinasyon marka eşitliği boyutları ile ilişkini test etmişlerdir. Araştırma sonucunda; "destinasyon kalite, imaj, sadakat ve farklılık algisı" ile turistlerin destinasyon "seyahat niyetleri" arasında; "destinasyon aşinalığ 1 ile turistlerin seyahat niyetleri ve destinasyon farklılık algısı arasında ve destinasyon aşinalığı" ile turistlerin "seyahat niyetleri" ve destinasyon "kalite algısı" arasında yüksek ve pozitif düzeyde bir ilişki tespit edilmiştir. Destinasyon "aşinalık boyutu" ile turistlerin "seyahat niyetleri", destinasyon "imaj ve sadakat algısı" arasında önemli ancak yönü belirsiz bir ilişki tespit edilmiştir. Genel olarak "araştırma modeline dâhil edilen boyutların" turistlerin "seyahat niyetlerine" yüksek ve pozitif düzeyde etkilerinin olduğu belirlenmiştir. Bu çalışmada da yabancı turistlerin destinasyon seyahat niyetlerine destinasyon marka eşitliği ve destinasyon aşinalığ boyutlarının etki düzeylerinin belirlenmesi amaçlanmaktadır.

\section{YÖNTEM}

Bu bölümde araştırmanın modeli, araştırma hipotezleri, veri toplama araçları, veri toplama teknikleri ve araştırma verilerinin analizi detaylandırılmaktadır. 


\section{Araştırmanın Modeli}

İlgili araştırma amacı doğrultusunda turistlerin destinasyonlarla ilgili algıladıkları marka eşitliği boyutlarının "(destinasyon kalite algısı, destinasyon imaj algisı, destinasyon sadakat algisı ve destinasyon farklılık algısı)" "seyahat niyetlerine" etkisi ve yine "destinasyon aşinalık boyutunun" destinasyon "seyahat niyetleri" boyutlarına etkisini keşfetmek için Destinasyon Marka Eşitliği, Destinasyon Aşinalığı ve Seyahat Niyeti Modeli (Şekil 1) oluşturulmuştur. Araştırma modelinin oluşturulma sürecinde Chi vd., (2020) yararlanılmıştır.

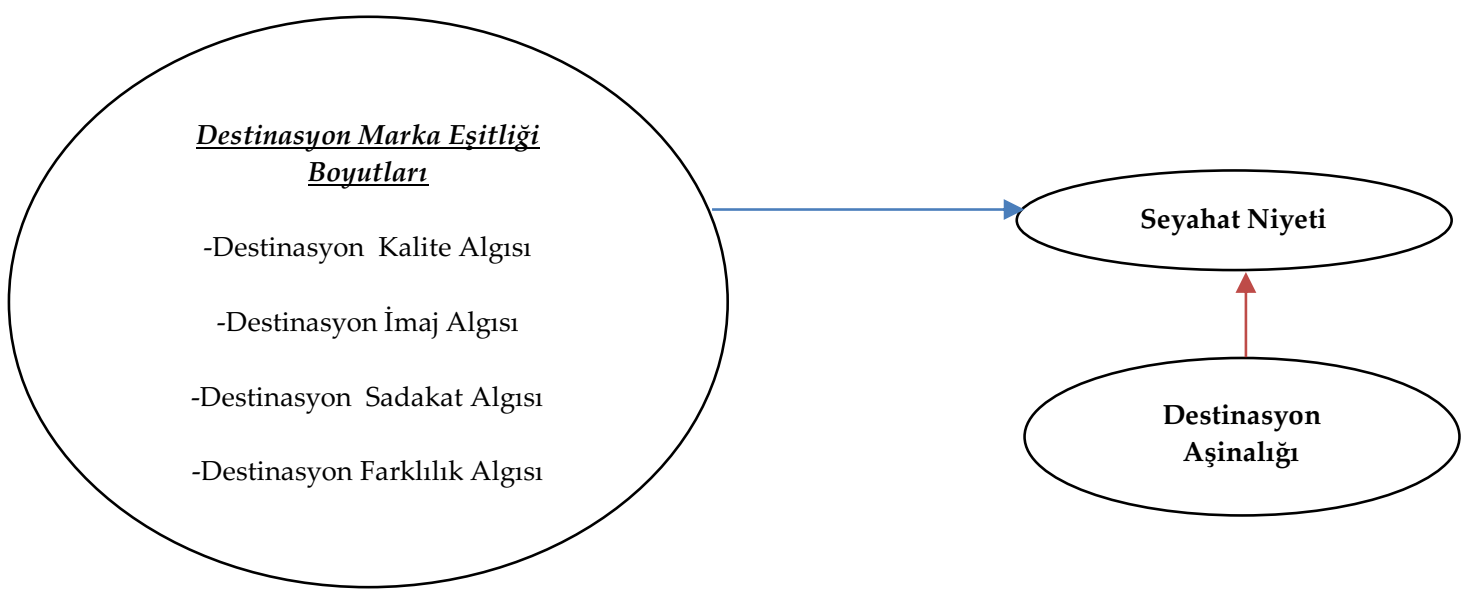

Şekil 1. Turistlerin Destinasyon Marka Eşitliği, Destinasyon Aşinalığı ve Seyahat Niyeti Modeli (DME-DA-SN).

\section{Araştırma Hipotezleri}

İlgili araştırma modelinden hareketle aşağıda verilen hipotezlerin araştırma analizleri kapsamında test edilmelerine karar verilmiştir.

Hipotez 1. Turistlerin destinasyonlarla ilgili algıladıkları kalite düzeyi seyahat niyetlerini etkilemektedir. Turistlerin destinasyonlarla ilgili kalite algıları destinasyon marka eşitliğinde önemli bir bileşendir ve turistlerin destinasyon seyahat niyetlerini pozitif düzeyde etkilemektedir (Boo vd., 2009; Chi vd., 2020).

Hipotez 2. Turistlerin destinasyonlarla ilgili algıladıkları destinasyon imajı seyahat niyetlerini etkilemektedir. Destinasyon marka imajı turistlerin destinasyonlarla ilgili zihinlerinde oluşan marka algısını ifade etmektedir ve destinasyonlarla ilgili turistlerin algıladıkları marka imajı düzeyi destinasyon seyahat niyetlerini pozitif düzeyde etkilemektedir (Arendt ve Brettel, 2010; Chi vd., 2020).

Hipotez 3. Turistlerin destinasyonlarla ilgili algıladıkları destinasyon sadakati seyahat niyetlerini etkilemektedir. Destinasyon marka sadakati turistlerin destinasyonlarla ilgili tekrar ziyaret niyetlerini, destinasyon hakkındaki sosyal çevrelerine, potansiyel turistlere, vb. deneyim paylaşımlarını ve destinasyonlarla ilgili turistlerde oluşan marka sadakati genel olarak turistlerin destinasyon seyahat niyetlerini pozitif düzeyde etkilemektedir (Yoon ve Uysal, 2005; Ferns ve Walls, 2012; Chi vd., 2020).

Hipotez 4. Turistlerin destinasyonlarla ilgili algıladıkları destinasyon farklılığı seyahat niyetlerini etkilemektedir. Destinasyon marka farklılığı turistlerin destinasyonları fark etmesini veya hatırlamasını ifade etmektedir ve marka eşitliği çalışmalarında önemli bir bileşeni 
oluşturmaktadır (Taşcı, 2018). Destinasyonlarda marka farklılığı oluşturma çabaları (ayırt edici marka yaratma, marka değeri oluşturma, özel ve duygusal bağ oluşturma, reklam, vb.) turistlerin destinasyon seyahat niyetlerini pozitif düzeyde etkilemektedir (Yuan ve Jang, 2008; Chi vd., 2020).

Hipotez 5. Turistlerin destinasyonlarla ilgili algıladıkları destinasyon aşinalık düzeyleri seyahat niyetlerini etkilemektedir. Destinasyon aşinalığı; turistlerin önceki seyahatlerini tekrarlamasının veya turistlerin bir destinasyonu ilk kez veya belirli aralıklarla ziyaret etmelerinin nedenleri çeşitli yönleriyle açıklamaya çalışan bir kavramdır (Milman ve Pizam, 1995; Chi vd., 2020). Destinasyon aşinalığının turistlerin destinasyon marka eşitliği boyutları ve destinasyon seyahat niyetleri üzerinde pozitif etkiye sahiptir. Çünkü destinasyonlarla ilgili aşinalık düzeyi düzeyi arttıkça turistlerde bilgi arama çabası azalmaktadır, güvenlik ve rahatlık hissi artmaktadır ve bunların pozitif bir sonucu olarak seyahat niyeti oluşmaktadır (Baloğlu, 2001; Lin vd., 2014; Chi vd., 2020).

\section{Araştırmanın Veri Toplama Yöntemi}

Araştırmanın veri toplama sürecinde anket tekniğinden yararlanılmıştır. Yapılan bu çalışmada da iki bölümden oluşan bir anket kullanılmıştır. Anketin ilk bölümü katılımcıların demografik özelliklerini belirlemeye yönelik yedi sorudan ve bu sorulara yönelik cevaplandırıcının seçebileceği ifadelerden oluşmaktadır. Anketin ikinci bölümünde ise katılımcıların DME boyutuna yönelik kalite algısı (dört ifade), imaj algısı (dört ifade), sadakat algısı (beş ifade) ve farklılık algısı (beş ifade) alt boyutlarını; destinasyon aşinalık boyutunu (beş ifade) ve destinasyon seyahat niyeti boyutunu (üç ifade) belirlemeye yönelik 5-Kesinlikle Katılıyorum ve 1-Kesinlikle Katılmıyorum aralığında toplam 26 Likert tipi ifadeye yer verilmiştir. Araştırmada kullanılan ölçek ve liker tipi ifadeler ilgili alanyazın kapsamında farklı yazarlarca geliştirilmeye başlanmıştır ve Chi vd., (2020) ölçeğin son halini test etmişlerdir. Bu çalışmada anketin içerik geçerliğinin sağlanması, çeviri ve dil bilim konularında uzman kişilerin görüşlerinden yararlanılmıştır.

\section{Araştırma Alanı Seçim Süreci}

İstanbul destinasyonunun araştırma alanı olarak seçilmesinde; 8500 yıllık tarihi geçmişi ve sahip olduğu kültürel değerleri, dünyaca ünlü doğal güzellikleri, gastronomik zenginlikleri ve yüzyıllardır farklı medeniyetlerin beşiği konumunda olmasından dolayı sahip olduğu yerel kültürü, destinasyonun UNESCO Dünya Mirası Listesi'ne kabul edilmiş birçok yapıya ve esere ev sahipliği yapması, ulusal ve uluslararası çok çeşitli organizasyonlara ev sahipliği yapmasından dolayı tanınırlı̆̆ ve bilinirliği, 2019 yılı sonu itibariyle Türkiye'nin en çok turist çeken destinasyonu olması (16 milyona yakın) ve ilgili konu kapsamında destinasyonda daha önce herhangi bir çalışmanın yapılmamış olması etkili olmuştur (www.istanbul.ktb.gov.tr, 2020). İlgili destinasyonda Ortadoğu ülkelerinden turistlerin tercih edilmesinde ise destinasyonla olan kültürel, tarihi, fiziki, dini, sosyal, vb. yakınlıkları ve benzerlikleri, son yıllarda sağlık, iş ve kongre turizmi başta olmak üzere diğer tatil gereksinimlerini geçirmek üzere İstanbul destinasyonunu yoğun şekilde ziyaret etmeleri belirleyici olmuştur.

\section{Araştırma Evreni ve Örneklemi}

Araştırmanın evrenini İstanbul destinasyonunu ziyaret eden ve Ortadoğu ülkelerinden (Suudi Arabistan, Katar, Kuveyt, İran ve Mısır başta olmak üzere diğer çekirdek Ortadoğu ülkeleri) 
gelen ziyaretçilerin bütünü oluşturmaktadır. Araştırma örneklemini ise veri toplama süresi içerisinde ilgili destinasyonu ziyaret eden ve Ortadoğu ülkelerinden gelen yabancı turistler oluşturmaktadır. Ancak bu araştırmanın veri toplama süreci içerisinde (Ağustos-Kasım 2019) ilgili destinasyonu tam olarak kaç kişinin ziyaret ettiği ve bu ziyaretçilerin ne kadarının Ortadoğulu turistlerden oluştuğu tespit edilememiştir. Bu sebeple araştırma örneklemini hesaplamak için hedef kitledeki birey sayısının bilinmediğinden hareketle; " $\mathrm{n}=\mathrm{t}^{2} \mathrm{pq} / \mathrm{d}^{2}$ formülden" yararlanılmıştır (Yazıcıŏglu ve Erdoğan, 2007:70). Formül çerçevesinde ilgili değerleri yerine koyarsak araştırma örneklem sayısı; $n=(1,96)^{2}(0,5) \times(0,5) /(0,05)^{2} ; n=0,9535 / 0,0025$; n=384 olarak belirlenmiştir. Hesaplanan örneklem büyüklüğüne ulaşmak için araştırma katılımcılarının belirlenmesi sürecinde olasılığa dayalı olmayan örnekleme yöntemlerinden kasti (kararsal-amaçlı) örnekleme yönteminden yararlanılmıştır. Bu örnekleme yönteminde araştırmacı problemine cevap bulacağına inandığı kişileri kendisi seçer (Altunışık vd., 2007:132). Araştırmaya yönelik verilerin elde edilmesi için Ortadoğu ülkelerinden gelen ziyaretçilere 430 tane anket formu dağıtılmıştır. Ancak geri dönüş sağlanan anketlerden 21 tanesi her soruya aynı cevabın kodlanması ve dokuz anket ise cevap kodlamalarının \%50'sinden fazlasının boş bırakılmasından dolayı değerlendirme dışında bırakılmıştır. Araştırmanın değerlendirme kısmına 400 anket dâhil edilmiştir ve anketlerin geri dönüş oranı \%93 olarak gerçekleşmiştir.

\section{Araştırma Analizleri}

Araştırma sonucunda anketlerden elde edilen veriler bilgisayara kaydedilerek veri seti oluşturulmuştur. İlgili veri seti SPSS istatistiki veri programında analize tabi tutulmuştur. Araştırma anketinden elde edilen Ortadoğulu turistlerin demografik değişkenlerine ilişkin veriler yüzde ve sıklık değerleriyle analiz edilmiştir. Sıklık analizinden sonra ölçekteki likert tipi ifadelerin güvenirliği analiz edilmiştir. Değişkenlerin güvenirlik analizinde Alpha modelinden yararlanılmıştır. Güvenirlik analizinden sonra ölçeğin yapı geçerliğini test etmek amacıyla açıklayıcı faktör analizi yapılmıştır. Araştırmada ayrıca ilgili araştırma boyutları regresyon analizine dâhil edilmiştir.

\section{BULGULAR}

\section{Katılımcılara İlişkin Bulgular}

Araştırmanın örneklem özelliklerine ilişkin genel bir değerlendirmenin yapılabilmesi için uygulanan sıklık analizi (Tablo 1) sonuçlarına göre katılımcıların çoğunluğu erkek (\%60), 25-60 yaş aralığında (\%49), lisans düzeyinde eğitime sahip (\%53), özel sektör çalışanı (\%35), 2001\$$5000 \$$ aralığında aylık gelire sahip (\%40), alışveriş (\%29) ve tatil-gezip görme, vb. (\%24) amaçlı seyahat eden ve birden fazla kez destinasyonu ziyaret etmiş (\%59) turistlerden oluşmaktadırlar.

\section{Güvenilirlik Analizi Bulguları}

Bir araştırmada güvenirlik analizi; herhangi bir konuda örneklemi oluşturan birimler üzerinden veri toplamak amacı ile oluşturulan ifadelerin kendi aralarında tutarlı olup olmadığını test etmek amacıyla yapılır (Ural ve Kılıç, 2005:258). Bu araştırmada kullanılan ölçeğin Cronbah's Alpha katsayısı ,880 olarak bulunmuştur. Elde edilen katsayı oranları ölçeklerin güvenilir olduğuna işaret etmektedir. 
Tablo 1. Araştırmaya Katılan Turistlerin Demografik Özelliklerine Göre Dağılımları ( $n=400)$

\begin{tabular}{|c|c|c|c|}
\hline Demografik Özellikler & & (n) & $(\%)$ \\
\hline Cimol & Kadın & 160 & 40,0 \\
\hline Cinsiyet & Erkek & 240 & 60,0 \\
\hline & $15-24$ yaş aralığ & 110 & 27,5 \\
\hline Yaş & $25-60$ yaş aralığ1 & 195 & 48,8 \\
\hline & 61 yaş ve üzeri & 95 & 23,7 \\
\hline & Lise ve Altı & 30 & 7,5 \\
\hline & Önlisans & 76 & 19,0 \\
\hline Eğitim Düzeyi & Lisans & 210 & 52,5 \\
\hline & Lisansüstü & 84 & 21,0 \\
\hline & Öğrenci & 125 & 31,0 \\
\hline & Özel sektör çalışanı & 140 & 35,2 \\
\hline Meslek & Kendi işini yapan & 95 & 23,7 \\
\hline & Kamu çalışanı & 22 & 5,5 \\
\hline & Emekli & 18 & 4,5 \\
\hline & 2000 \$ ve daha az & 135 & 33,8 \\
\hline Aylık Gelir & $2001 \$-5000 \$$ arasi & 160 & 40,0 \\
\hline & 5001 \$ ve üzeri & 105 & 26,2 \\
\hline & İş, Fuar, Kongre, Sergi, vb. & 75 & 18,7 \\
\hline Destinasyonu Ziyaret & Alışveriş & 115 & 28,7 \\
\hline Amaciniz & Tatil, Gezip Görme, vb. & 95 & 23,7 \\
\hline & Sağlık & 66 & 16,6 \\
\hline & Eğitim & 49 & 12,3 \\
\hline Destinasyonu Ziyaret & İlk ziyaret & 165 & 41,2 \\
\hline Sayısı & Birden fazla ziyaret & 235 & 58,8 \\
\hline & & 400 & 100 \\
\hline
\end{tabular}

\section{Faktör Analizi Bulguları}

Bu çalışmada açıklayıcı faktör analizinden yararlanılmıştır. Faktör analizi ile Kaiser-Meyer-Olkin (KMO-Örnekleme Yeterliliği İstatistiği) ve Bartlett's Test of Sphericity (Bartlett's Küresellik Testi) elde edilmektedir. Bartlett's küresellik testi faktör analizi yapabilmek için değişkenler arasında gerekli olan ilişki düzeyinin yeterli olup olmadığını göstermektedir $(\mathrm{p}<0,05)$. Aynı şekilde KMO örneklem yeterliği de değişkenler arası korelâsyonun faktör analizi için yeterli olup olmadığına karar vermede kullanılır (Durmuş vd., 2010:79-80). Açıklayıcı faktör analizi sonucunda; sig. $(\mathrm{p})=0,000$ anlamlılık düzeyinde $\mathrm{KMO}$ değeri ,854 olarak belirlenmiştir. Ayrıca Barlett's Testi sonucu 1968,128 olarak tespit edilmiştir. Bu oranın düzeyi ve elde edilen KMO değeri örneklem büyüklügünün faktör analizi için yeterli ve uygun olduğunu göstermektedir. Çalışmada hem faktör yükleri açısından küçük hem de katsayısı küçük ifadeler (communalities) değerlendirme dışı bırakılarak faktör analizinin geçerliliğinin arttırılması amaçlanmıştır. Yapılan bu iki işlem sonucunda ölçekte yer alan 26 ifadeden sadece bir tanesinin (Bu destinasyona seyahat edecek olsam arkadaşlarımın aklına bu mutlaka gelir.) ölçekten çıkartılmasına karar verilmiştir. Faktör analizi sonucunda özdeğeri birden büyük 25 ifadeden oluşan altı boyut (DME-DA-SN ölçeği) belirlenmiştir. Bu boyutlar toplam varyansın \%69,913'ünü açıklamaktadır. Araştırmada elde edilen varyans oranı alınyazına göre kabul edilebilir bir düzeydedir (Altunışık vd., 2007:347). Araştırmada faktör analizine ilişkin olarak Chi vd., (2020) çalışması referans alınmıştır ve ilgili boyutlar; Destinasyon Farklılık Algısı (DFA), Destinasyon İmaj Algısı (DİA), Destinasyon Kalite 
Alg1sı (AKA), Destinasyon Sadakat Alg1sı (DSA), Destinasyon Seyahat Niyeti (DSN) ve Destinasyon Aşinalığı (DA) olarak adlandırılmıştır. Ayrıca yabancı turistlerin araştırma ölçeği boyutlarını değerlendirmelerine yönelik sonuçlara göre (Tablo 2); destinasyon farklılığ1 $(\tilde{\mathrm{x}}=4,45)$, destinasyon imajı $(\tilde{\mathrm{x}}=4,56)$, destinasyon kalitesi $(\tilde{\mathrm{x}}=4,38)$, destinasyon sadakati $(\tilde{\mathrm{x}}=4,61)$, seyahat niyeti $(\tilde{\mathrm{x}}=4,51)$ ve destinasyon aşinalığ $1(\tilde{\mathrm{x}}=4,18)$ boyutlara katılımları yüksek ve pozitif düzeydedir.

Tablo 2. Araştırmaya Ölçeğine (PDT-UA) İlişkin Faktör Analizi Sonuçları (n=400)

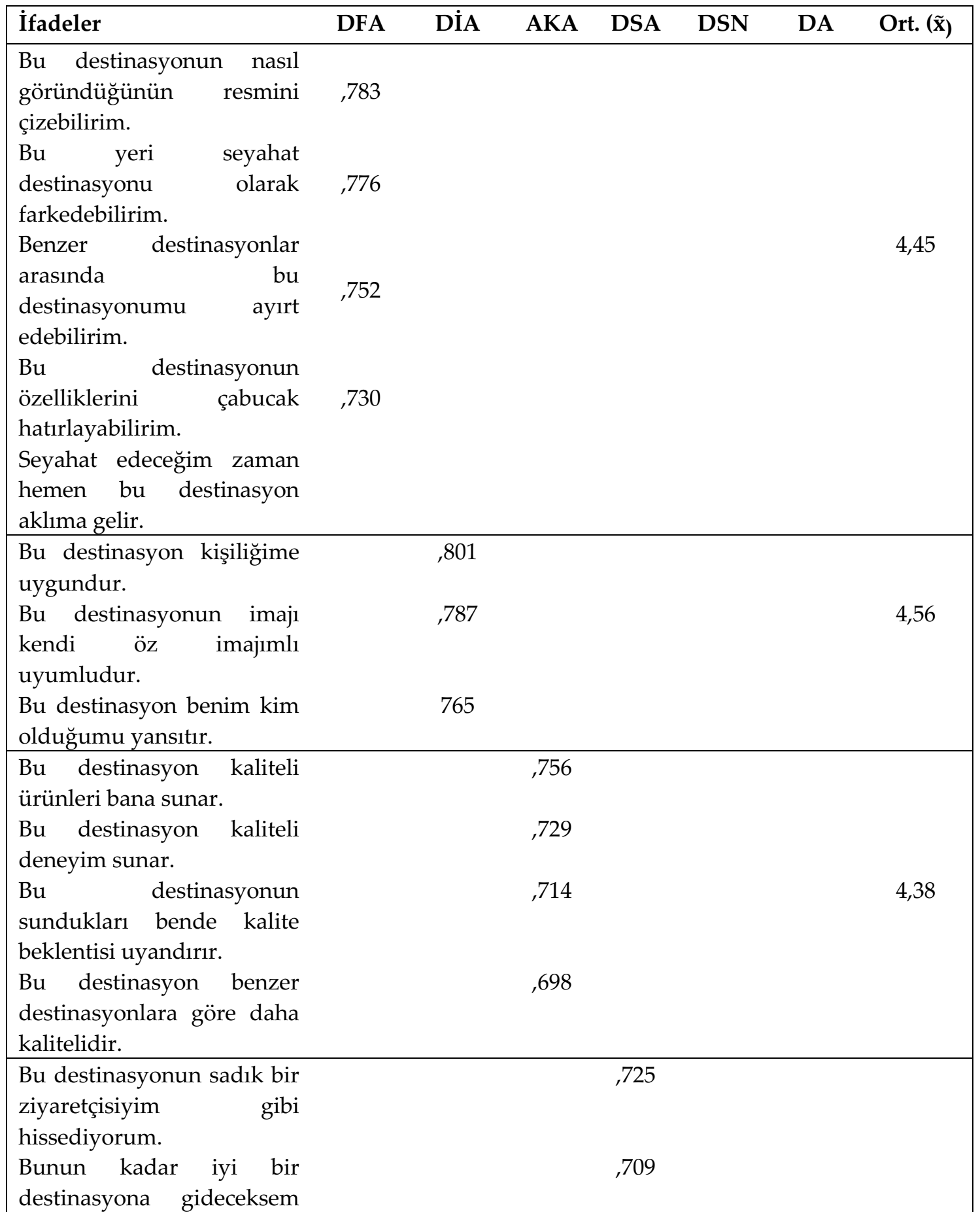


tercihim bu destinasyon

olur.

Bu destinasyon seyahatim

için ilk tercihimdir.

$\mathrm{Bu}$ destinasyon yerine

başka bir destinasyona

gidersem tercihim bunun

benzeri olur.

$\mathrm{Bu}$ destinasyonu seyahat

etmeleri için diğer arkadaşlarıma da öneririm.

Gelecek yıl seyahat edersem tercihim yine bu destinasyon olur.

Gelecek yıl seyahat edersem planım yine bu destinasyon olur.

Tatil için yine bu destinasyona gelmeyi çok isterim.

Ortalama bir insana göre çok çeşitli destinasyonlara aşinayım diyebilirim.

Ortalama bir arkadaşıma göre çok çeşitli destinasyonlara aşinayım diyebilirim.

Sik sik destinasyonlar ,785 , 656 hakkında bilgi toplamak için zaman harcarım.

Ben destinasyonlar , 717

hakkındaki bilgilere genel olarak aşinayım.

\begin{tabular}{|c|c|c|c|c|c|c|}
\hline Özdeğerler & 5,356 & 3,789 & 3,121 & 2,344 & 2,007 & 1,765 \\
\hline Güvenilirlik Analizi-Alpha & ,901 & 878 & ,890 & 865 & 834 & 870 \\
\hline Açıklanan Varyans (\%) & 19,156 & 15,678 & 10,357 & 9,989 & 8,585 & 7,148 \\
\hline Toplam Açk. Varyans (\%) & \multicolumn{6}{|c|}{69,913} \\
\hline KMO Yeterliği & \multicolumn{6}{|c|}{,854 } \\
\hline Bartlett's Küresellik Değeri & \multicolumn{6}{|c|}{1968,128} \\
\hline Sig. $p$ değeri & \multicolumn{6}{|c|}{0,000} \\
\hline
\end{tabular}

\section{Regresyon Analizi Bulguları}

Regresyon analizi; bağımlı bir değişken ile bu değişken üzerinde etkisi olduğu varsayılan bağımsız değişken veya değişkenler arasındaki ilişkinin istatistiksel bir model ile açıklanmasıdır (Ural ve Kılıç, 2005:225). Bu çalışmada öncelikle DME boyutları bağımsız değişken ve destinasyon seyahat niyeti bağımlı değişken ve sonrasında ise destinasyon aşinalığı bağımsız değişken ve destinasyon seyahat niyeti boyutu bağımlı değişken olarak regresyon analizine tabi 
tutulmuştur. Araştırma hipotezlerinin test edilmesi amacıyla yapılan regresyon analizi sonuçlarına göre (Tablo 3) turistlerin destinasyon seyahat niyetlerini açiklayan DME boyutlarını belirlemeye yönelik regresyon modelinin bir bütün olarak anlamlı olduğu görülmektedir $(\mathrm{F}=38,336 ; \mathrm{p}<0,05)$. Beta değerlerinin anlamlılık düzeyleri incelendiğinde ise tüm $\mathrm{DME}$ boyutlarının turistlerin destinasyon seyahat niyetlerini etkilediği görülmektedir. Bu çerçevede tüm DME boyutlarının yüksek ve pozitif düzeyde turistlerin destinasyon seyahat niyetlerini etkilediğini söylemek mümkündür. Ayrıca turistlerin destinasyon seyahat niyetlerini açklayan destinasyon aşinalığı boyutunu belirlemeye yönelik regresyon modelinin (Tablo 3) bir bütün olarak anlamlı olduğu görülmektedir $(\mathrm{F}=25,148 ; \mathrm{p}<0,05)$. Beta değerlerinin anlamlılık düzeyleri incelendiğinde ise destinasyon aşinalığı boyutunun turistlerin destinasyon seyahat niyetlerini etkilediği görülmektedir. Bu çerçevede destinasyon aşinalı̆̆ 1 boyutunun yüksek ve pozitif düzeyde turistlerin destinasyon seyahat niyetlerini etkilediğini söylemek mümkündür. Regresyon analizi sonuçlarına göre DME boyutlarının turistlerin destinasyon seyahat niyetlerini pozitif şekilde ve turistlerin destinasyon aşinalıklarının destinasyon seyahat niyetlerini yüksek ve pozitif düzeyde etkilediği tespit edilmiştir. İlgili sonuçlar çerçevesinde tüm araştırma hipotezleri kabul edilmiştir.

Tablo 3. DME-DA-SN Boyutlarına İlişkin Regreasyon Analizleri

\begin{tabular}{|ccccccccc|}
\hline & Boyutlar & Beta & $t$ & $p$ & $r^{2}$ & $\boldsymbol{F}$ & VIF & Hipoezler \\
\hline & DKA &, 667 & 2,349 &, 000 &, 346 & & 1,345 & H 1 Kabul \\
SN & DİA &, 482 & 2,487 &, 000 &, 297 & 38,336 & 1,256 & H 2 Kabul \\
& DSA &, 501 & 4,567 &, 000 &, 261 & & 1,651 & H 3 Kabul \\
& DFA &, 467 & 2,109 &, 000 &, 247 & & 1,489 & H4 Kabul \\
\hline SN & DA &, 809 & 6,123 &, 000 &, 956 & 25,148 & 3,865 & H 5 Kabul \\
\hline
\end{tabular}

\section{TARTIŞMA, SONUÇ VE ÖNERİLER}

$\mathrm{Bu}$ çalışmada İstanbul ilini ziyaret eden ve Ortadoğu ülkelerinden gelen yabancı turistlerin seyahat niyetlerine destinasyon marka eşitliği ve destinasyon aşinalığı boyutlarının etkisinin belirlenmesi amaçlanmaktadır. Bu kapsamda yapılan araştırma analizlerinin sonuçlarına göre katılımcıların çoğunluğu erkek, 25-60 yaş aralığı, lisans düzeyinde eğitime sahip, özel sektör çalışanı, 2001 \$-5000 \$ aylık gelire sahip, alışveriş amaçlı ve birden fazla kere destinasyonu ziyaret etmiş kişilerden oluşmaktadırlar. Araştırmada analizlerinin sonuçlarına göre araştırma ölçeği boyutları Chi vd., (2020) referans alınarak destinasyon farklılık algısı, destinasyon imaj algısı, destinasyon kalite algıSı ve destinasyon sadakat algısı şeklinde adlandırılmıştır. Katılımcıların destinasyon sadakat algis1, destinasyon imaj alg1s1, destinasyon seyahat niyeti, destinasyon farklılık algıSı, destinasyon kalite algısı ve destinasyon aşinalığı boyutlarına katılımları yüksek ve pozitif düzeyde gerçekleşmiştir. Araştırma da ayrıca tüm destinasyon marka eşitliği boyutlarının ve destinasyon aşinalığ pozitif ve yüksek düzeyde etki ettiği sonucuna ulaşılmıştır. Yapılan bu araştırmanın ilgili alanyazına, destinasyon yönetim örgütlerine ve sonraki çalışmalara elde edilen uygulama sonuçları itibariyle katkı sağlayacağı düşünülmektedir. Çünkü ilgili konu başlı̆̆ında Türkçe alanyazında ve uygulama sonuçları anlamında İstanbul veya Türkiye'deki herhangi bir destinasyonda çalışmaya ulaşılamamıştır. Ayrıca destinasyon marka eşitliği konularında Türkçe ve yabancı alanyazında çeşitli çalışmalar yürütülmüşse de seyahat niyeti ve destinasyon aşinalığ 1 ilişkilerini de destinasyon marka eşitliği boyutları ile ilişkilendiren çalışmalar yok denecek kadar azdır. Diğer yandan araştırma analizlerinden elde edilen sonuçların destinasyonların planlama 
ve pazarlama çalışmalarında yarar sağlayacağı düşünülmektedir. Çünkü destinasyonların markalaşma ve farklılık yaratma süreçlerinde turistlerin destinasyonlara ilişkin kalite, imaj, sadakat ve farklılık algılarının ve ayrıca "aşina olma" durumlarının da turistlerin destinasyon seyahat niyetlerine etki ettikleri mutlaka dikkate alınmalıdır (Milman ve Pizam, 1995; Tan ve Wu, 2016; Chen vd., 2017; Gürsoy vd., 2018; Hahm ve Severt, 2018). Aşina olma durumu turislerde güvenlik hissi, kaygılarının azalması ve bilgi arama çabalarında ve sürelerinde tasarrufa katkı sağlamaktadır. Destinasyonlar arasında ulusal ve uluslararası yaşanan yoğun rekabet, turistlerin alternatif bilgi edinme araçlarının ve kaynaklarının sayılarındaki artış, küresel ölçekte destinasyonlara erişimin ve ulaşımın kolaylaşması, vb. destinasyonlar arasında turistik talebi kendilerine yönlendirme noktasında kıyasıya bir mücadeleyi de beraberinde getirmektedir. $\mathrm{Bu}$ noktada başarı sağlamak ve turistik talebi kendilerine çekmek isteyen destinasyonlar turistlerde kendileri ile ilgili endişeleri azaltmak, memnuniyeti sağlamak, turistlerin doğru bilgi edinmelerine katkı sunmak ve turistlerde sadakat oluşturabilmek adına turistlerin kendilerini deneyimlemelerine olanak sağlayan ortamları (fuarlarda, toplu taşıma ortamlarında, vb. destinasyon deneyim alanlarının oluşturulması, vb.) sanal veya gerçekliği arttırılmış uygulamaları, sosyal medya kullanıcılarının yorumlarını ve tavsiyelerini turistlerin kullanımına sunmaları gerekmektedir. Bu sayede turistlerin satın alma süreçlerinde yaşadıkları belirsizlikler nispeten de olsa ortadan kaldırılabilir ve destinasyon aşinalık hissi yaratılabilir. Ayrıca araştırma ifadelerinden de anlaşılacağı üzere destinasyona gelen turistler üzerinde kalite, imaj, sadakat ve farklılık oluşturularak sonraki tatil deneyimlerinde ve destinasyon seçim süreçlerinde aşinalık durumundan yararlanılarak talebin tekrar aynı destinasyona çekilmesi mümkün olacaktır. Mevcut turistlerin sosyal çevrelerini ve referans gruplarını etkileme gücü dikkate alındığında bu sürecin doğru yürütülmesi daha da önem kazanmaktadır. Destinasyonların imaj çalışmaları ve turistlerde algılanış düzeylerinin ölçülmesi, destinasyonlarda sunulan turistik ürünlerin ve hizmetlerin yüksek kalitede ve farklılaştırılmış bir perspektiften sunulması, turistlerden memnuniyetin ve sadakatin sağlanması destinasyonların uzun vadede varlıklarını sürdürmelerinde, rekabet güçlerini arttırmalarına, yeni turistleri kazanma adına katlanılacak maliyetlerin minimize edilmesine, yeni turist kazanma çabalarının mevcut çalışmalara ve süreçlere yönlendirilmesine olumlu katkılar sağlayacaktır.

Araştırma maddi kaynaklar ve zaman sınırlığından dolayı örneklem büyüklügüu alanyazında kabul edilen sinırlar içerisinde olmakla birlikte daha geniş bir örneklem büyüklüğüne uygulanamamıştır. Gelecekteki çalışmalarda araştırmaya dâhil edilecek ziyaretçilerin milletlerinin çeşitliliğinin ve örneklem kapsamının arttırılması araştırma sonuçlarının genellenmesi açısından olumlu katkılar sağlayacaktır. Ayrıca ölçeğe yapılacak yeni eklemeler ve demografik değişkenlerde yapılacak değişiklikler ile farklı değişkenler açısından ziyaretçilerin destinasyon seyahat niyetlerinin ölçülmesi mümkün hale gelecektir.

\section{KAYNAKÇA}

Altunışık, R., Çoşkun, R., Bayraktaroğlu, S. ve Yıldırım, E. (2007). Sosyal Bilimlerde Araştırma Yöntemleri SPSS Uygulamalı. (Geliştirilmiş Beşinci Baskı), Sakarya: Sakarya Yayıncılık.

Arendt, S. and Brettel, M. (2010). Understanding the Influence of Corporate Social Responsibility on Corporate Identity, Image and Firm Performance, Managament Decision, 48(10): 1469-1492.

Baloğlu, S. (2001). An Investigation of a Loyalty Typology and the Multidestination Loyalty of International Travelers, Tourism Analysis, 6(1): 41-52.

Boo, S., Busser, J. and Baloğlu, S. (2009). A Model of Customer-Based Brand Equity and Its Application to Multiple Destinations, Tourism Management, 30(2): 219-231. 
Chen, C-C. and Lin, Y-H. (2012). Segmenting Mainland Chinese Tourists to Taiwan by Destination Familiarity: A Factor-Cluster Approach, International Journal of Tourism Research, 14(4): 339-352.

Chen, C-C., Chung, Y. J. Gao, J. and Lin, Y-H. (2017). Destination Familiarity and Favorability in A Country-Image Context: Examining Taiwanese Travelers' Perceptions Of China, Journal of TravelETourism Marketing, 34(9): 1211-1223.

Chi, K-H., Huang, K-C. and Nguyen, M. H. (2020). Elements of Destination Brand Equity and Destination Familiarity Regarding Travel Intention, Journal of Retailing and Consumer Services, 52: $1-10$.

Durmuş, B., Yurtkoru, E. S. ve Çinko, M. (2007). Sosyal Bilimlerde SPSS'le Veri Analizi. (Tıpkı Üçüncü Basım), İstanbul: Beta Yayıncllı.

Ferns, H. B. and Walls, A. (2012). Enduring Travel Involvement, Destination Brand Equity and Travelers' Visit Intentions: A Structural Model Analysis, Journal of Destination MarketingEManagement, 1(1-2): 27-35.

Garcia, A. J., Gomez, M. and Molina, A. (2012). A Destination-Branding Model: An Empirical Analysis Based on Stakeholders, Tourism Management, 33(3): 646-661.

Gürsoy, D. and McCleary, W. K. (2004). An Integrative Model of Tourists' Information Search Behavior, Annals of Tourism Research, 31(2): 353-373.

Gürsoy, D. Del Chiappa, G. and Zhang, Y. (2018). Impact of Destination Familiarity on External Information Source Selection Process, Journal of Destination Marketing \& Management, 8: 137-146.

Hahm, J. and Severt, K. (2018). Importance of Destination Marketing on Image and Familiarity, Journal of Hospitality and Tourism Insights, 1(1): 37-53.

https://istanbul.ktb.gov.tr/TR-165064/genel-bilgiler.html [Erişim Tarihi: 01.02.2020).

Keller, L. K. (2003). Understanding Brands, Branding and Brand Equity, Interactive Marketing, 5(1): 7-20.

Kim, H-B. and Kim, G. W. (2005). The Relationship between Brand Equity and Firms' Performance in Luxury Hotels and Chain Restaurants, Tourism Management, 26(4): 549-560.

Lepp, A. and H. Gibson (2003). Tourist Roles, Perceived Risk and International Tourism, Annals of Tourism Research, 30 (3): 606-624.

Lin, H. Y., Lin, J. F. and Ryan, c. (2014). Tourists' Purchase Intentions: Impact of Franchise Brand Awareness, The Service Industries Journal, 34(9-10): 811-827.

Milman, A. and Pizam, A. (1995). The Role of Awareness and Familiarity with a Destination: The Central Florida Case, Journal of Travel Research, 33(3): 21-27.

Murphy, L., Beckendorff, P. and Moscardo, G. (2007). Destination Brand Personality: Visitor Perceptions of a Regional Tourism Destination, Tourism Anylsis, 12(5-6): 419-432.

Pike, S. D. and Bianchi, C. (2013). Destination Branding Performance Measurement: A NonTechnical Discussion for Practitioners, Tourism Tribune, 28(1), 13-15.

Ritchie, O. E. and Ritchie, J. R. B. (1996). The Service Experience in Tourism. Tourism Management, 17(3): 165-174. 
Tan, W-K. and Wu, C-E. (2016). An Investigation of the Relationships Among Destination Familiarity, Destination Image and Future Visit Intention, Journal of Destination MarketingEManagement, 5(3): 214-226.

Taşçı, A. and Knutson, B. J. (2004). An Argument for Providing Authenticity and Familiarity in Tourism Destinations, Journal of Hospitality Marketing and Management, 11(1): 85-109.

Ural, A. ve Kılıç, İ. (2005). Bilimsel Araştırma Süreci ve SPSS ile Veri Analizi, Ankara: Detay Yayıncilik.

Yazıcıoğlu, Y. ve Erdoğan, S. (2007). SPSS Uygulamalı Bilimsel Araştırma Yöntemleri. (Genişletilmiş İkinci Baskı), Ankara: Detay Yayıncılık.

Yuan, J. and Jang, S. (2008). The Effects of Quality and Satisfaction on Awareness and Behavioral Intentions: Exploring the Role of a Wine Festival, Journal of Travel Research, 46(39): 279-288.

Yoon, Y. and Uysal, M. (2005). An Examination of the Effects of Motivation and Satisfaction on Destination Loyalty: A Structural Model, Tourism Management, 26(1): 45-56. 